\title{
A cidade vivida nos espaços de arte pela perspectiva da leveza
}

The city lived in art spaces from the perspective of lightness

\section{Paulo Celso Silva}

Professor do PPG Comunicacão e Cultura da Uniso

\section{Cássia Pérez da Silva}

Mestranda pelo Programa de Pós-Graduação Interunidades em Estética e História da Arte (PGEHA) da Universidade de São Paulo (USP)

\section{RESUMO}

Neste artigo, para tratar das relações urbanas, recorremos às obras de land art da artista Agnes Denes, cuja estética remete a um engajamento sociopolítico. Foram escolhidos, para análise, três de seus trabalhos, apresentados em Nova York: Rice/Tree/Burial; Wheatfield - A Confrontation; e A forest for New York - A peace park for mind and soul. Ao intervir no cotidiano da cidade, a artista permite ao transeunte refletir sobre os territórios em que o viver acontece. Ele pode buscar em um campo de trigo a leveza que o homem contemporâneo experimenta em aparatos tecnológicos de comunicação (os quais, inclusive, carrega consigo para registrar momentos fugidios na e da cidade). Em relação ao conceito de leveza, recorremos ao filósofo francês Gilles Lipovetsky, para quem, na contemporaneidade, a leveza escorre da ordem do imaginário para a do real por meio de um processo de miniaturização. Contrariando essa perspectiva, Agnes Denes ocupa grandes pedaços dos espaços de reserva do capital para trazer à tona a leveza. Este artigo pensa, ainda, o cotidiano e a necessidade de superá-lo do ponto de vista de Heller, Amorim Soares e Santos.

PALAVRAS-CHAVE: Cidade; Arte; Agnes Denes; Comunicação. 


\section{ABSTRACT}

In this article, to discuss urban relations, we analyze works of land art by the artist Agnes Denes, whose aesthetics refer to a socio-political engagement. Three interventions were chosen for that purpose, all of them in New York: Rice / Tree / Burial; Wheatfield - A Confrontation; and A forest for New York - A peace park for mind and soul. By intervening in the daily life of the city, the artist allows the passerby to reflect on the territories in which living happens. It can seek in a wheat field the lightness that contemporary people experience in technological communication devices (which they can even carry to record fleeting moments in and of the city). For the concept of lightness, we use the approach of French philosopher Gilles Lipovetsky, for whom a lightness now flows from the order of the imaginary to the order of the real through a process of miniaturization. Contrary to this expectation, Agnes Denes occupies acres of spaces of capital reserve to bring out lightness. The article also thinks about daily life and the necessity to overcome it from the perspective of Heller, Amorim Soares and Santos. KEYWORDS: City; Art; Agnes Denes; Communication.

Eu encontrei a terra das fadas bem aqui ao meu lado. Quando eu morava em South Jersey, não havia tempo para o devaneio, e a vida era mais simples. Você não era incomodado, você não tinha pessoas tentando te prender ou coisas doidas assim... Mas isso era tudo que havia. Não havia chance de extensão, não havia chance de ser destruído ou de realmente ser criado lá... Era apenas viver. E isso é ok para algumas pessoas, mas eu sempre senti algo diferente se movimentando em mim, e é por isso que eu vim para cá. Porque eu sabia que havia coisas dentro de mim que poderiam florescer. Talvez eu me arruinasse. Talvez eu me sentisse péssima. Mas pelo menos isso sairia de mim. Se não, não havia como isso chegar à superfície. Nova York foi o que me seduziu. Nova York foi o que me formou. Nova York foi o que me deformou. Nova York foi o que me perverteu. Nova York foi o que me converteu. E Nova York é o que eu amo. Essa é minha pequena oração por Nova York.

Patti Smith, 1969. 


\section{Introdução}

Parece acertado reconhecer que a materialidade das cidades está ligada a momentos em que o imaginário é fator preponderante. Este não age solitário, mas estimulado por imagens e discursos veiculados em vários suportes, fixos e móveis. Carregando um smartphone, podemos produzir fotos e vídeos dos processos nos quais estamos inseridos naquele momento e distribuí-los para outros usuários desta ou de quaisquer cidades, por exemplo.

As marcas deixadas pelo pesado concreto com que pontes e edifícios são construídos tornam-se leves quando distribuídas nos milhares de pontos de uma tela. Esses pontos podem mesmo ser considerados um discurso da cidade, construído, desconstruído e reconstruído como materialidade imediata e arquivável, para ser apagada, retomada, acreditada com o status de "verdade", graças ao registro e rastro deixados por eles.

Assim, pode-se dizer que uma das marcas da cultura contemporânea é a leveza, e uma outra, relacionada a ela, é a miniaturização dos produtos e serviços, a qual permite carregá-los pelos espaços.

A leveza dos fenômenos comunicacionais contemporâneos em que estamos imersos e pelos quais somos moldados se estende também para outros setores do vivido e do imaginado. Entretanto, na imensidão dos possíveis, também se relaciona à produção de resíduos e ao descarte de lixo.

Com base nessas experiências de produção e consumo na cidade, artistas vêm utilizando os territórios vividos para não só propor alternativas ao descarte de produtos, mas, a partir de ações e reflexões, propor a mudança de hábitos e ideias que atinjam o meio ambiente. Espécie de micro-utopia na qual o apelo estético e o ativismo social transformam o território imediatamente próximo, familiar a um grupo ou a uma maioria da população, que sente a suspensão do 
cotidiano. Por isso, nesses casos, a escala é da ordem do micro: não pode e não quer transformar todos os segmentos do social. Nesse sentido, a totalidade ganha nova dimensão e distancia-se dos discursos ou utopias coletivas. Como sugere Lipovetsky (2016, p. 11): “Vivemos sem grandes utopias coletivas. A última utopia é a dos ecologistas, embora seja um tipo particular de utopia baseada no medo, no terror. Diz-se o tempo todo que se as coisas continuarem como estão o planeta vai explodir. As utopias clássicas falavam de esperança".

Este artigo pretende abordar a questão da cidade tendo como ponto de partida o trabalho da artista Agnes Denes, estabelecida nos Estados Unidos. Nas propostas dessa artista contemporânea, podemos verificar como a leveza, aplicada à cultura das cidades, pode levar-nos para outra dimensão da crítica e da produção de espaços urbanos reflexivos.

\section{A vida cotidiana e sua suspensão}

Ainda que a totalidade, segundo Lipovetsky (2016), se distancie da utopia coletiva na contemporaneidade, a vida cotidiana migra para o centro da produção midiática e é explorada e veiculada à exaustão, podendo mesmo "viralizar" nas redes sociais. Em consequência, ela pode ganhar destaque nos meios de comunicação tradicionais, mesmo que não simultaneamente ao acontecimento, como aconteceu com a foto o menino sírio Alan Kurdi, morto tentando atravessar o Mar Mediterrâneo, que comoveu as redes sociais e veículos de mídia três anos após o acontecido.

Contudo, nas mídias, essa relação dialética entre totalidade(s) e fragmento(s) não é nova. Pode-se considerar um jornal diário como uma coleção de retalhos, flashes e/ou fragmentos do cotidiano, com poucas matérias e fatos sendo oferecidos ao leitor até o seu desfecho final (talvez as novelas publicadas nos diários chegassem a esse ponto de totalidade, mas, ainda assim, estavam fragmentadas nas páginas impressas). Como contraponto, o leitor participa da vida 
cotidiana como "homem inteiro, ou seja, o homem participa da vida cotidiana com todos os aspectos de sua individualidade, de sua personalidade" (Heller, 2000, p. 17) para validar ações e fatos pela sua funcionalidade. Eis a característica do cotidiano: se é útil, é verdadeiro.

Nessa dimensão pragmática, ultrapassar ou sair da condição imediata deixa de ser cotidiano e passa a constituir um estado de suspensão, e o ser genérico, que participa do gênero humano, vive, potencialmente, uma experienciação, a qual

\begin{abstract}
é sentida ao invés de pensada, sabida ou verbalizada. Experienciação ocorre no presente imediato. Não se trata de atributos generalizados de uma pessoa como traços, complexos ou disposições. Em lugar disso, a Experienciação é o que uma pessoa sente aqui e agora, neste momento. Experienciação é um fluxo constantemente mutável de sentimentos que torna possível para qualquer indivíduo sentir alguma coisa em qualquer dado momento (GENDLIN, 1961, p. 233)
\end{abstract}

A experienciação apresenta-se como uma etapa do processo de suspensão do cotidiano. É como ter um impacto ao mesmo tempo inicial e definitivo dos fluxos dialéticos de objetivação/subjetivação gerados pelo efeito estético. Para Agnes Heller (2000, p. 26), "as formas de elevação acima da vida cotidiana que produzem objetivações duradoras são a arte e a ciência". Ela cita ainda o trabalho e a moral como duas outras formas de suspender o cotidiano; destas, porém, não trataremos aqui.

É importante ressaltar a temporalidade e a espacialidade das obras de arte e dos/das artistas e, ainda, o fato de eles/elas estarem inseridos em um cotidiano, pois é exatamente esse cotidiano que permite o enfrentamento de problemas que culminam nas obras propostas. 0 "artista [...] tem sua particularidade individual enquanto [mulheres e] homens na cotidianidade; essa particularidade pode se manter em suspenso durante a produção artística [...], mas intervém na própria objetivação através de determinadas mediações" (Heller, 2000, p. 27), ou seja, a atividade criadora ocorre em processo marcado pelo histórico e o social.

Nesse percurso de experienciação, "compreender o contexto em que o sujeito se insere, assim como sua história de vida e a história da atividade, é 
fundamental para a compreensão das significações de que se apropriou o sujeito e das necessidades que o movem a criar" (Zanella et al., 2000, p. 540). Isso porque, no extremo da suspensão do cotidiano, ter-se-á atingido a homogeneização, que "significa, por um lado, que concentramos toda nossa atenção sobre uma única questão e 'suspenderemos' qualquer atividade durante a execução da anterior tarefa; e, por outro lado, que empregamos nossa individualidade humana na resolução dessa tarefa" (Heller, 2000, p. 27).

A autora vai ressaltar, entretanto, que essa "suspensão radical" não acontece para todas as pessoas, sendo algo excepcional para a maioria, uma vez que o caminho da homogeneização para o humano genérico - "produto e expressão de suas relações sociais, herdeiro e preservador do desenvolvimento humano" (Heller, 2000, p. 21) - não é uma prática comum. Artistas, cientistas, moralistas e trabalhadores não alienados seriam os mais indicados a experienciar essa "suspensão radical".

As obras de Agnes Denes, com intervenções no cotidiano da cidade de Nova York, podem representar um momento de suspensão. Faz-se necessário, nesse caso, a descrição, para localizar o leitor em seus processos socioespaciais.

\section{Agnes Denes no campo de trigo urbano}

Nascida em Budapeste em maio de 1938, Agnes Denes é conhecida como uma das principais artistas conceituais contemporâneas, com trabalhos que envolvem vários campos científicos, como filosofia, geografia, história e literatura, e nos quais a estética remete a um engajamento sociopolítico. Seu primeiro trabalho de land art em grande escala e com preocupações ecológicas foi Rice / Tree / Burial, realizado em 1968, em Sullivan County, Nova York. Compunha-se de três elementos interligados: um campo de arroz, árvores acorrentadas e uma cápsula do tempo para ser aberta em 2979, contendo um haiku, poema japonês 
cuja elaboração segue formas e rituais específicos, com métricas exatas (o corte é, aqui, a essência do poema, uma vez que "haiku" quer dizer "corte").

Como a própria artista definiu sua obra: "Foi um 'evento' simbólico e anunciou meu compromisso com questões ambientais e preocupações humanas. Foi também o primeiro exercício em eco-logic - um ato em eco-filosofia [...]. Este trabalho é considerado a primeira realização ecológica na arte pública"1 (Denes, 1968).

Nas imagens abaixo, vemos o processo de produção da obra, o qual a autora também qualificou como filosofia visual que desafia o status quo: "um processo complexo que explora as essências como formas de comunicação. Encontra métodos para colocar proposições analíticas em forma visual, define processos ilusórios e cria analogias entre campos divergentes e processos de pensamento"2 (Denes, 1968). Considerando que a artista se utiliza da land art como suporte para a composição da obra, o efêmero faz-se necessário para a contemplação e participação na obra e nos conceitos propostos por ela. Essa característica da land art permite que o espectador obtenha sua experiência a partir dos mais diversos meios, inserindo-se tanto no processo de criação quanto no resultado final, e não se limitando a uma participação física no interior da obra. Segundo Cauquelin (2005, p. 141) "os trabalhos de land art fazem do espectador não mais um observador-autor (...) mas uma testemunha de quem se exige a crença"; o espectador, então, participa como testemunha conceitual da obra e usufrui esteticamente do poder envolver-se em todas as etapas dela.

\footnotetext{
${ }^{1}$ No original: "It was a symbolic 'event' and announced my commitment to environmental issues and human concerns. It was also the first exercise in Eco-Logic - an act in eco-philosophy. I coined the words to be used 2 No original: "a complex process which explores essences as forms of communication. It finds methods to put analytical propositions into visual form, defines elusive processes and creates analogies among divergent fields and thought processes. It challenges the status quo and tests its own validity." Denes, A. (1968). "Rice/Tree/Burial with Time Capsule". Disponível em: <http://www.agnesdenesstudio.com/works2.html>.
} 



Figuras 1, 2, 3 e 4 - "Rice/Tree/Burial with Time Capsule”. (C) by Agnes Denes. Disponível em: <http://www.agnesdenesstudio.com/works2.html>.

Rice / Tree / Burial preparou Agnes Denes conceitualmente para outra obra de maior envergadura e destaque na cidade de Nova York, em 1982: Wheatfield - A Confrontation: Battery Park Landfill, Downtown Manhattan, a qual o "acadêmico e curador Jeffrey Weiss chamou de 'perpetuamente surpreendente... uma das grandes obras-primas transgressoras da land art"'3 (ArtForum, 2008).

A obra Wheatfield - A Confrontation dialoga com a cidade de New York, seus habitantes, valores e com a produção e reprodução do espaço. Antes de qualquer

\footnotetext{
${ }^{3}$ No original: "scholar and curator Jeffrey Weiss, has called 'perpetually astonishing ... one of Land Art's great transgressive masterpieces'” (ArtForum, 2008).
}

Dossiê Espaço Urbano e Imaginação Cultural - https://revistaecopos.eco.ufrj.br/

ISSN 2175-8689 - v. 22, n. 3, 2019

DOI: 10.29146/eco-pos.v22i3.27417 
análise mais detida, apresentamos as imagens feitas a partir da visão/leitura da própria autora:

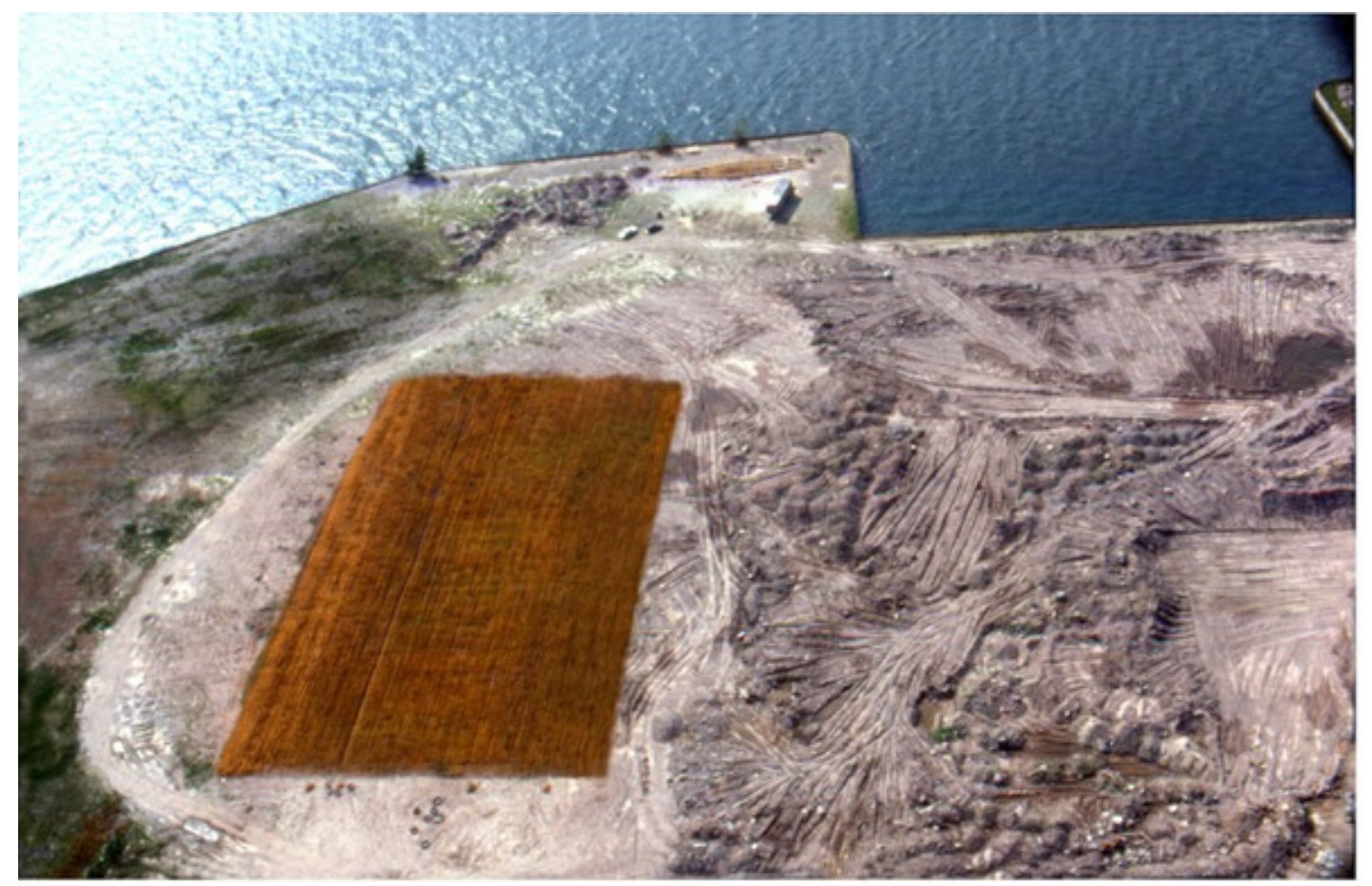

Figura 5 - Vista aérea de Battery Park no preparo do campo de trigo.

Dossiê Espaço Urbano e Imaginação Cultural - https://revistaecopos.eco.ufrj.br/

ISSN 2175-8689 - v. 22, n. 3, 2019

DOI: 10.29146/eco-pos.v22i3.27417 


\section{Fís DOSSIE}

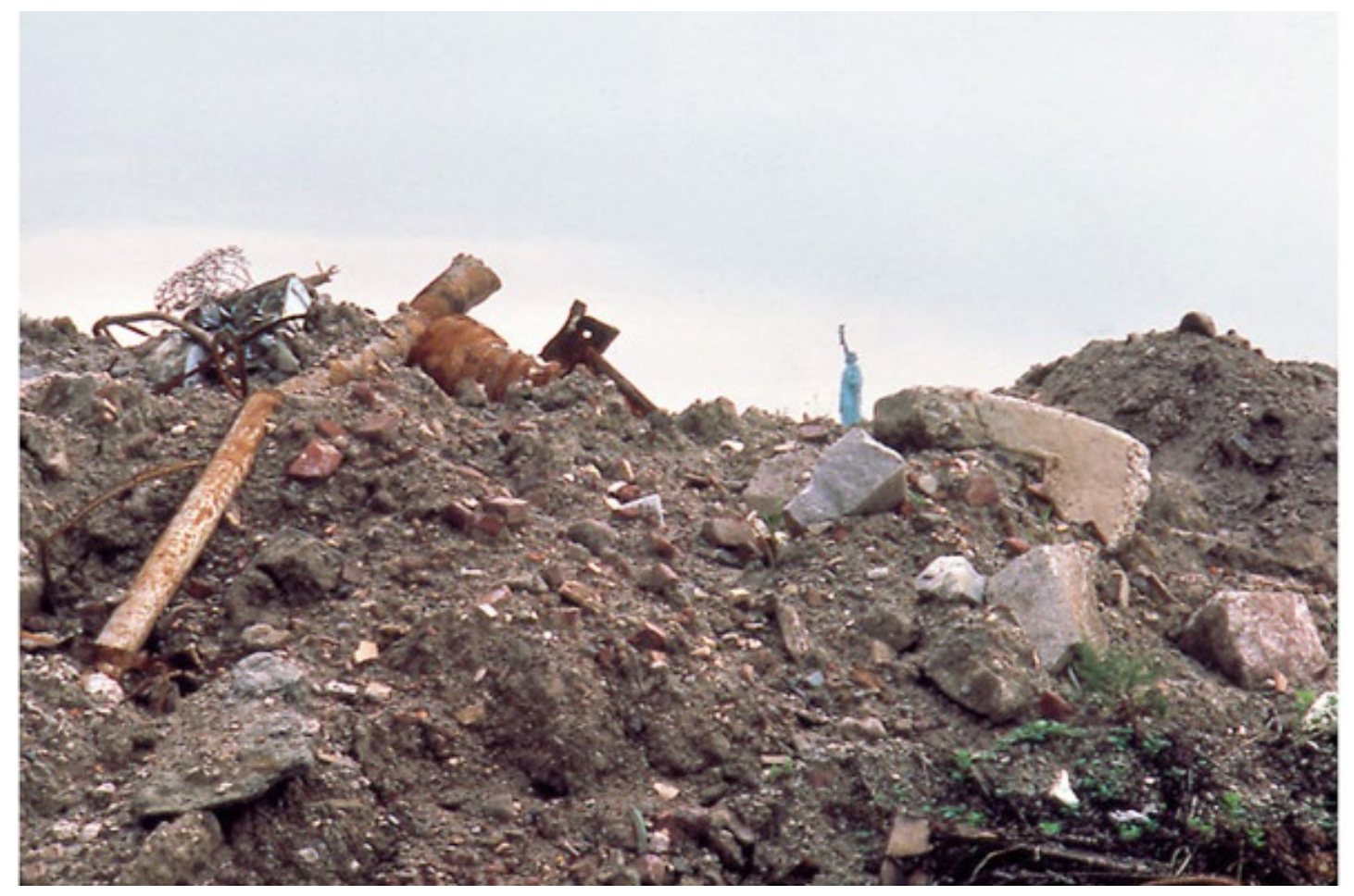

Figura 6 - Entulho e restos de construção do World Trade Center.

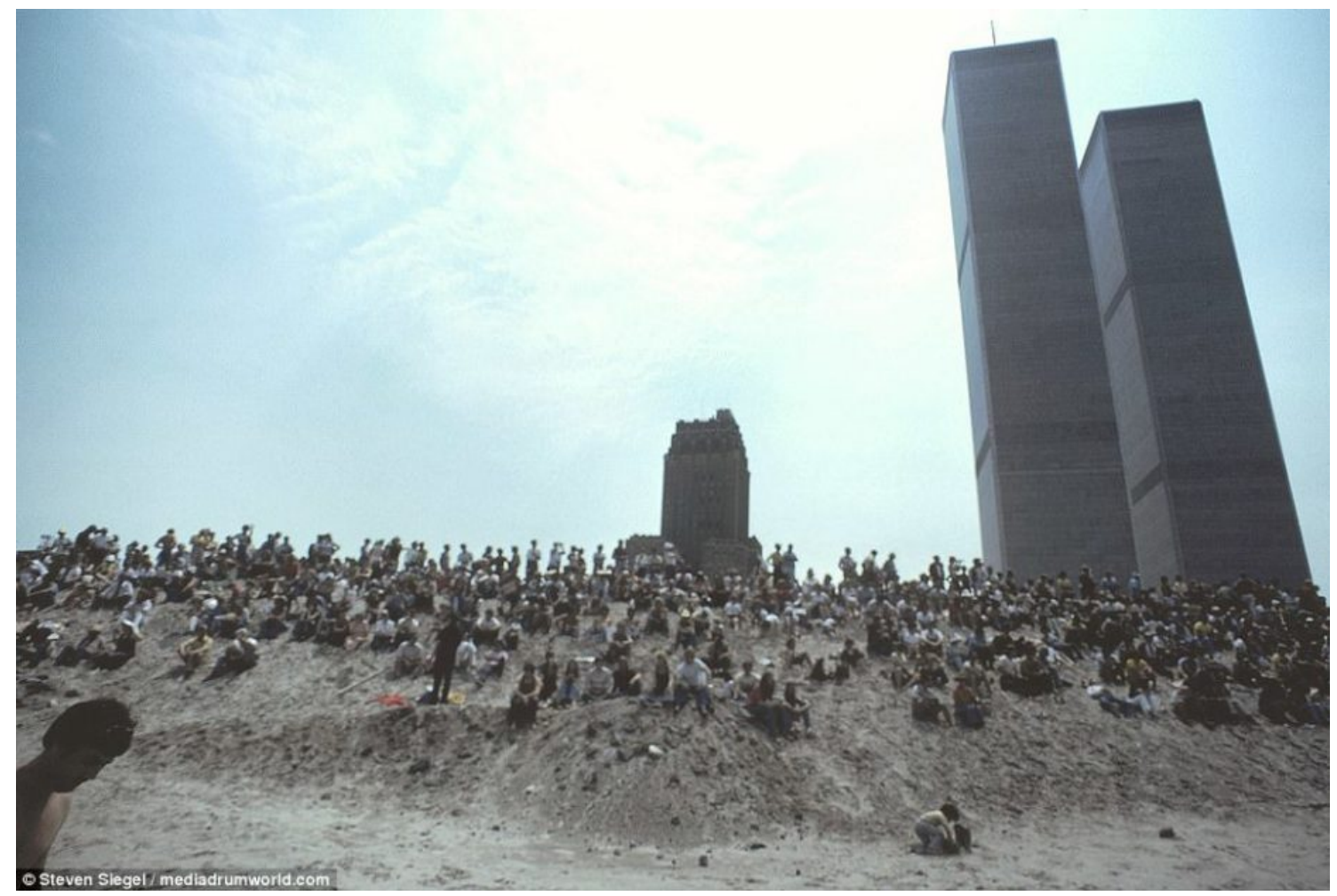

Figura 7 - Voluntários antes do início dos trabalhos.

Dossiê Espaço Urbano e Imaginação Cultural - https://revistaecopos.eco.ufrj.br/

ISSN 2175-8689 - v. 22, n. 3, 2019

DOI: 10.29146/eco-pos.v22i3.27417 


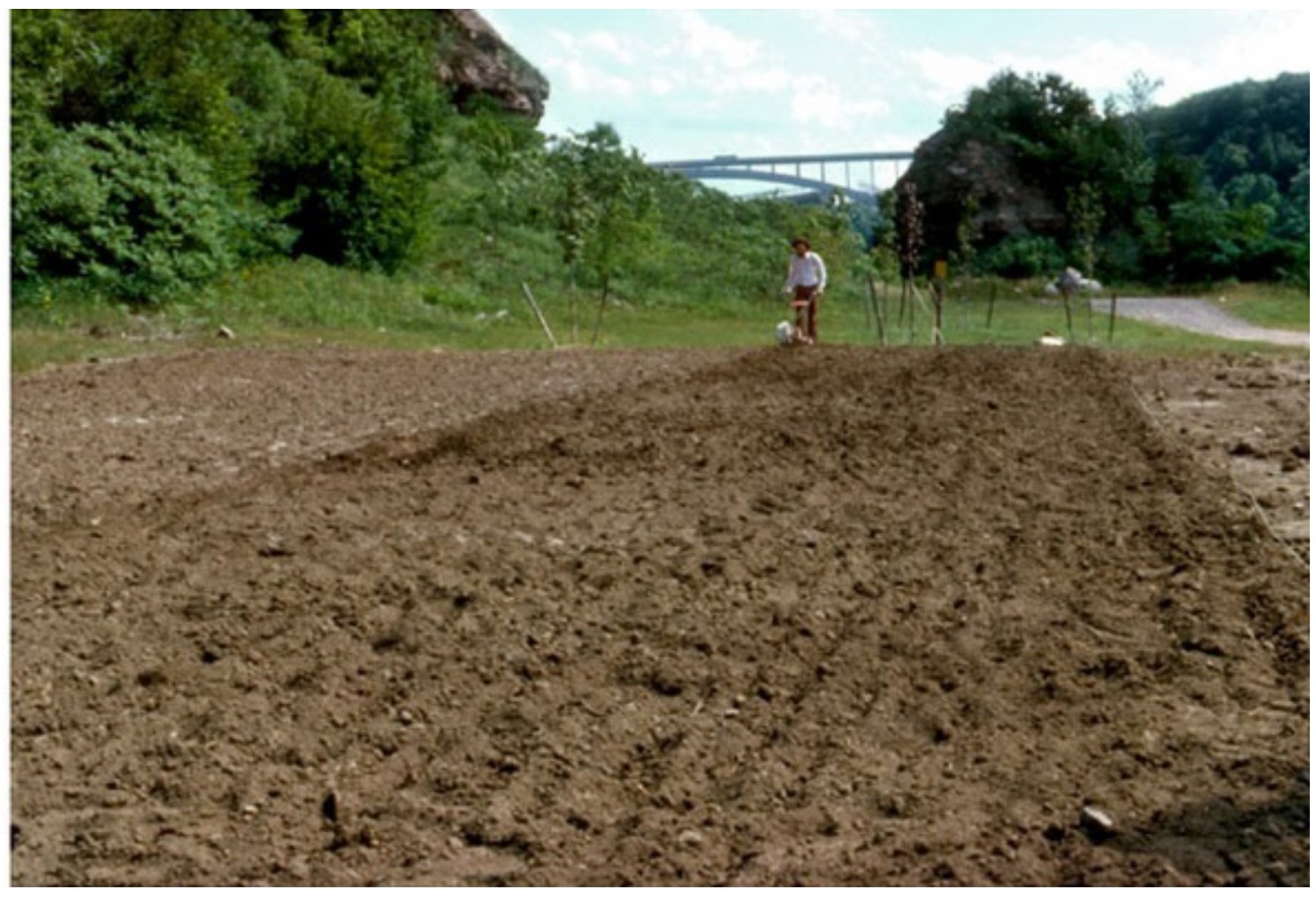

Figura 8 - Preparando a terra depois da retirada do entulho e colocação de terra fértil.

Dossiê Espaço Urbano e Imaginação Cultural - https://revistaecopos.eco.ufrj.br/

ISSN 2175-8689 - v. 22, n. 3, 2019

DOI: 10.29146/eco-pos.v22i3.27417 




Figura 9 - 0 trigo em crescimento.

Dossiê Espaço Urbano e Imaginação Cultural - https://revistaecopos.eco.ufrj.br/

ISSN 2175-8689 - v. 22, n. 3, 2019

DOI: 10.29146/eco-pos.v22i3.27417 


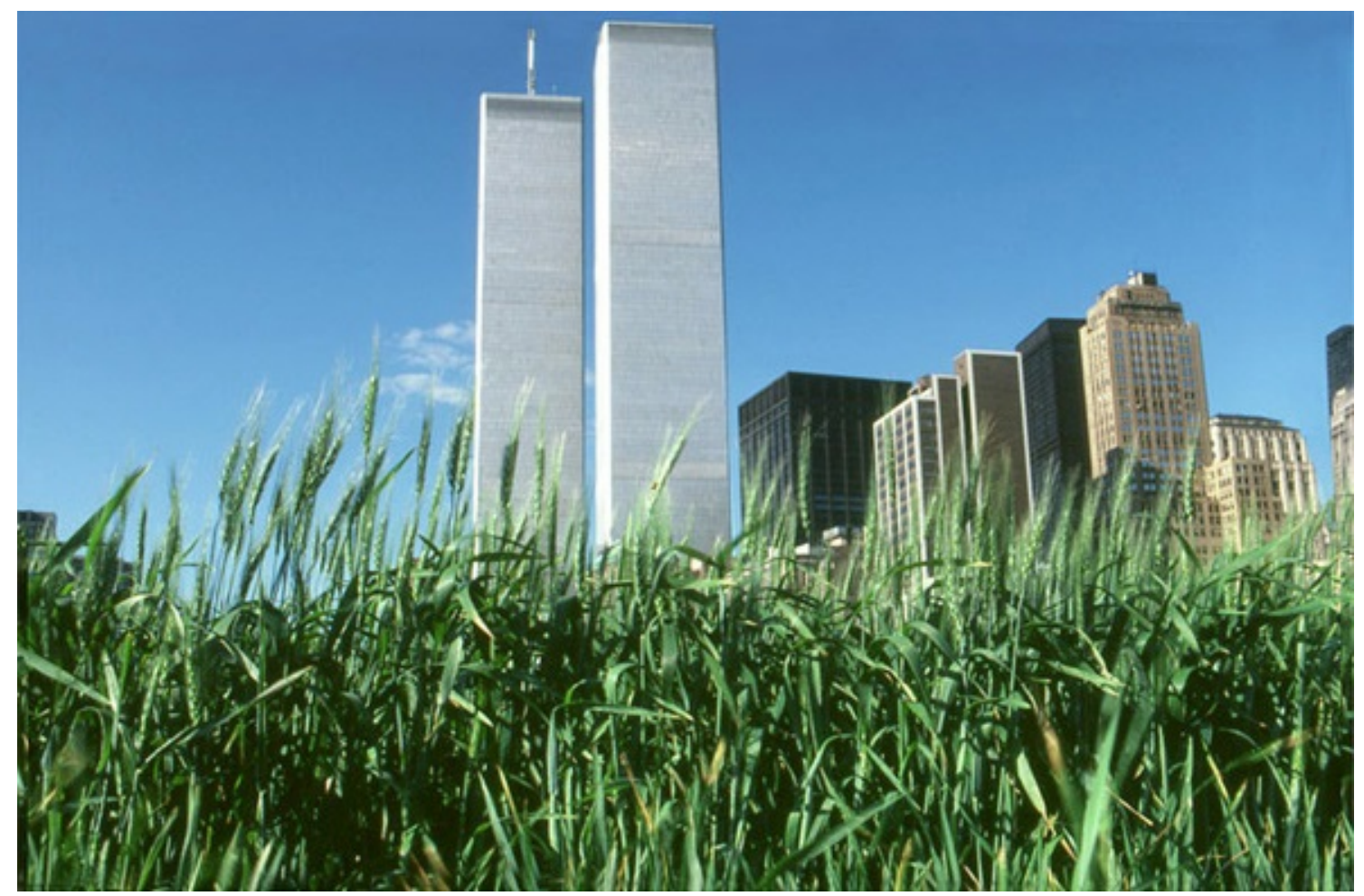

Figura 10 - 0 trigo com o World Trade Center em destaque.



Figura 11 - Campo de trigo em primeiro plano, navio e Estátua da Liberdade ao fundo.

Dossiê Espaço Urbano e Imaginação Cultural - https://revistaecopos.eco.ufrj.br/ ISSN 2175-8689 - v. 22, n. 3, 2019

DOI: 10.29146/eco-pos.v22i3.27417 


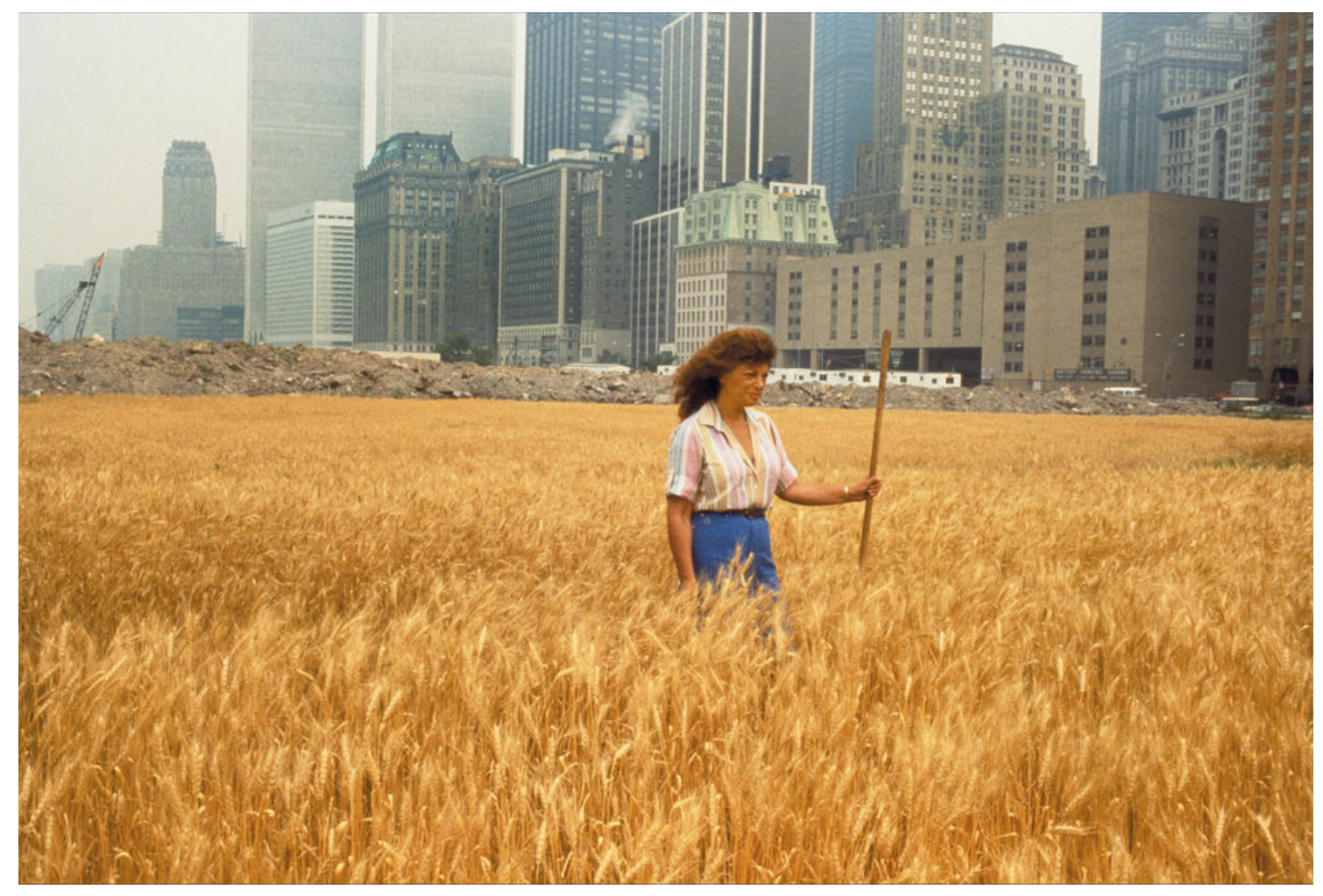

Figura 12 - Agnes Denes fotografada no campo de trigo. Photo: John McGrail. Type-C Print, 16 x 20", 1982.

Dossiê Espaço Urbano e Imaginação Cultural - https://revistaecopos.eco.ufrj.br/ ISSN 2175-8689 - v. 22, n. 3, 2019

DOI: 10.29146/eco-pos.v22i3.27417 


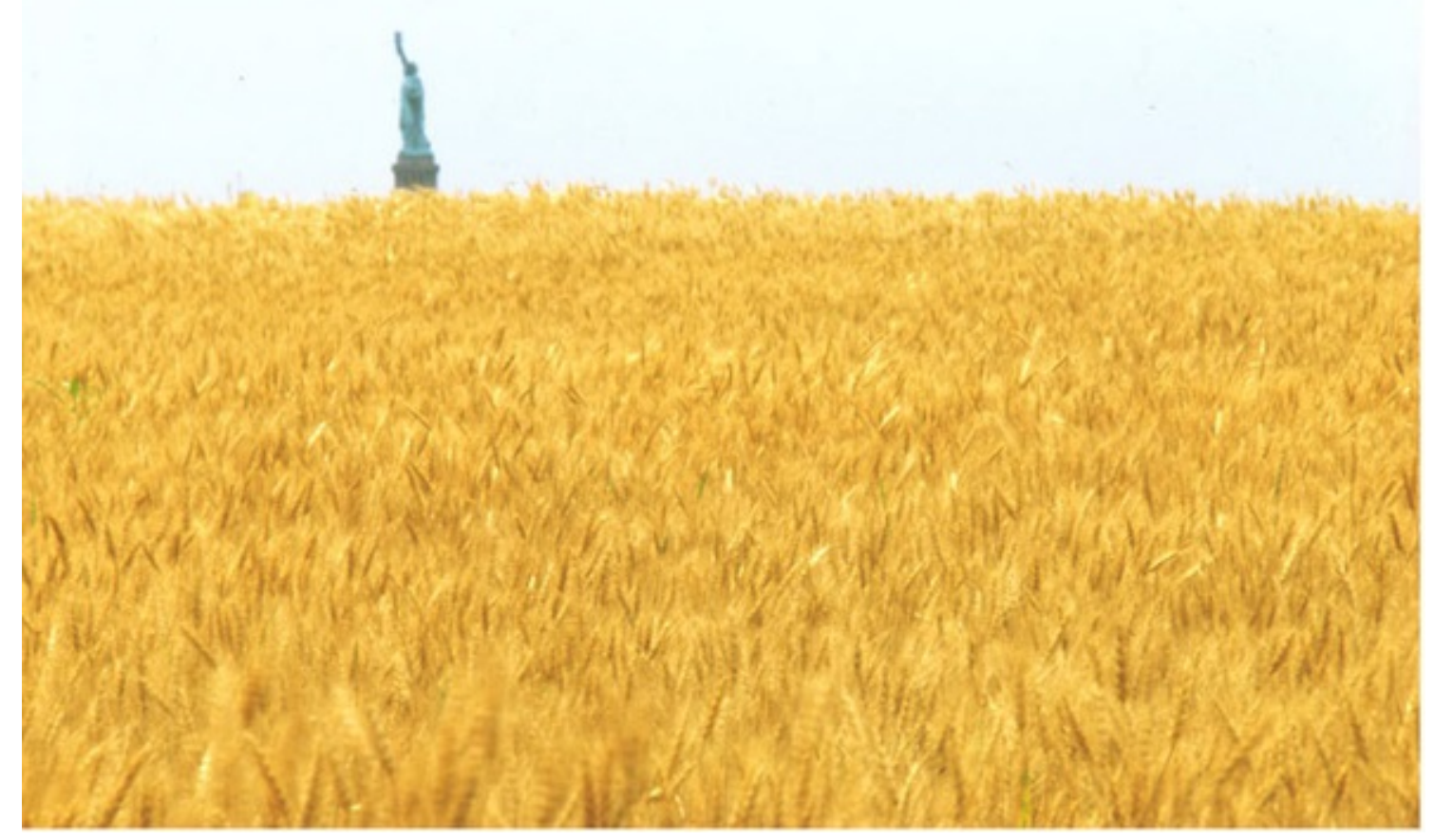

Figura 13 - Campo de trigo com estátua da liberdade ao fundo.

Dossiê Espaço Urbano e Imaginação Cultural - https://revistaecopos.eco.ufrj.br/

ISSN 2175-8689 - v. 22, n. 3, 2019

DOI: 10.29146/eco-pos.v22i3.27417 


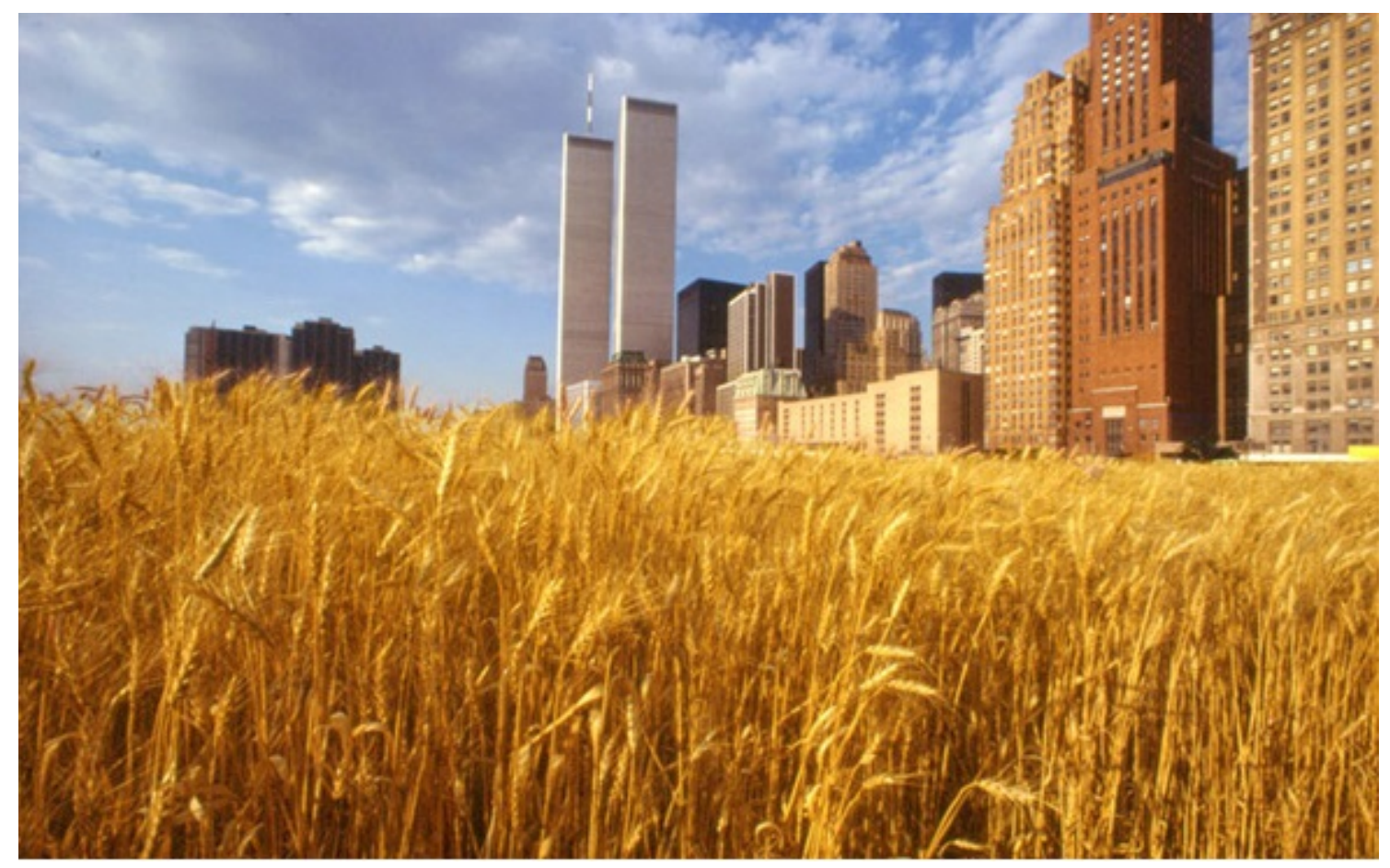

Figura 14 - Campo de trigo com World Trade Center ao fundo.

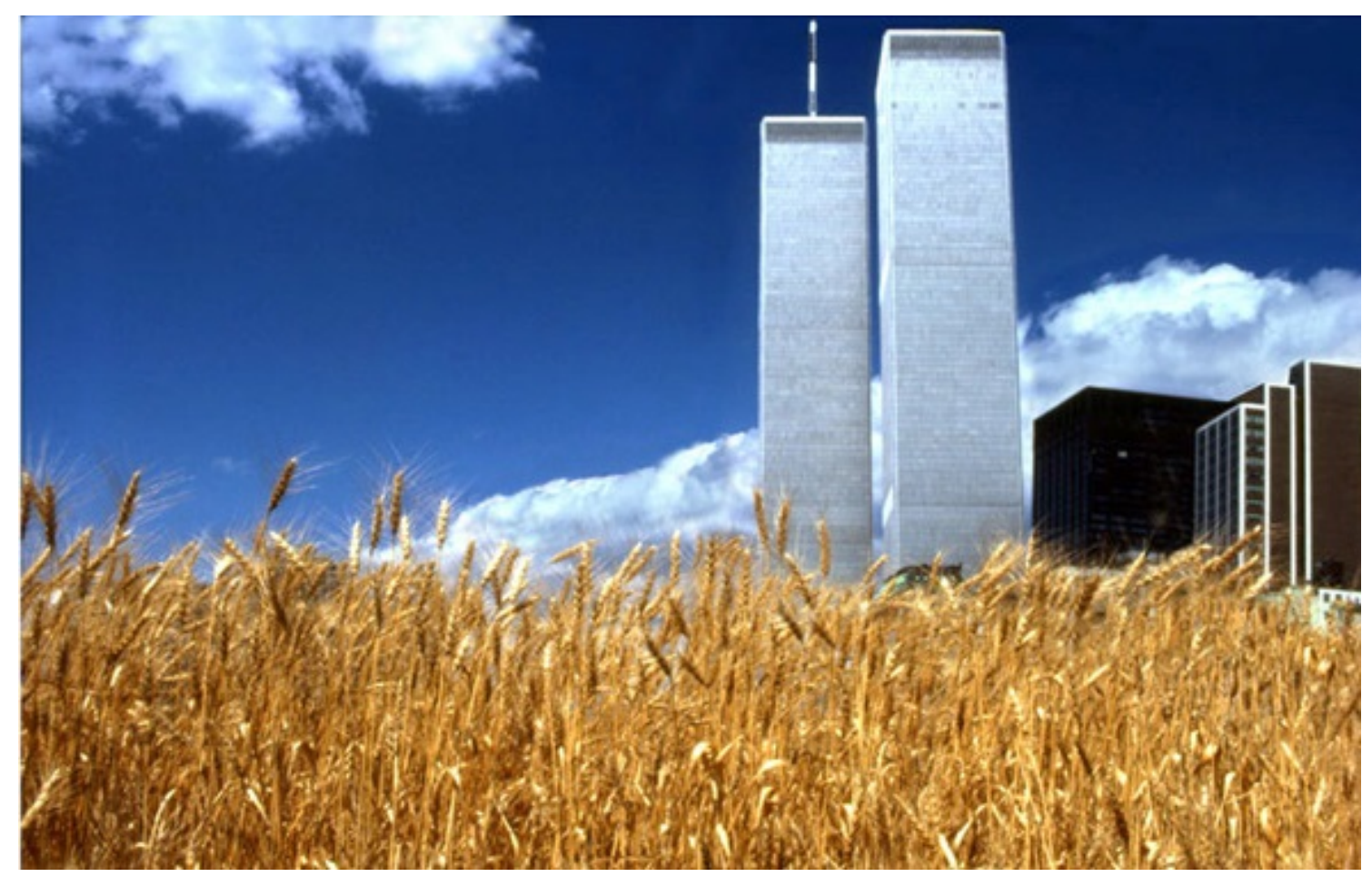

Figura 15 - Campo de trigo com World Trade Center ao fundo.

Dossiê Espaço Urbano e Imaginação Cultural - https://revistaecopos.eco.ufrj.br/ ISSN 2175-8689 - v. 22, n. 3, 2019

DOI: 10.29146/eco-pos.v22i3.27417 


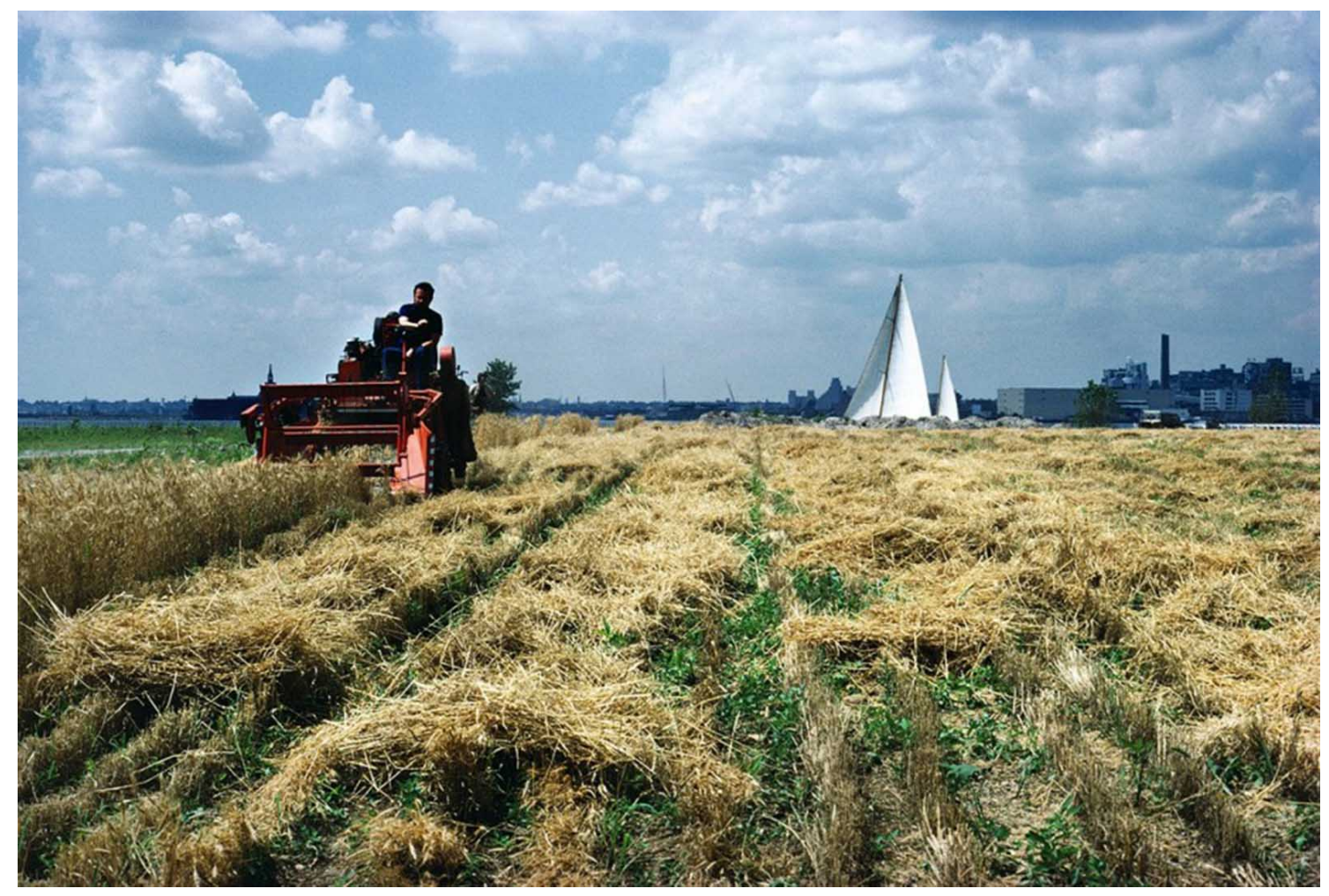

Figura 16 - Colheita do trigo.



Dossiê Espaço Urbano e Imaginação Cultural - https://revistaecopos.eco.ufrj.br/

ISSN 2175-8689 - v. 22, n. 3, 2019

DOI: 10.29146/eco-pos.v22i3.27417 
Figura 17 - A área em seu aspecto atual. Battery Park, Nova York. Renato Bonomini (https://www.flickr.com/photos/renatobo)

À época da intervenção artística urbana, Agnes Denes escreveu um artigo em que explicava a metodologia e as motivações para executar Wheatfield - $A$ Confrontation, assim como sua repercussão:

\section{Dois acres de trigo plantados e colhidos pela artista no aterro Battery Park, Manhattan, verão de 1982.}

Após meses de preparativos, em maio de 1982, um campo de trigo de 2 acres foi plantado em um aterro sanitário na parte baixa de Manhattan, a duas quadras de Wall Street e do World Trade Center, em frente à Estátua da Liberdade. Duzentos caminhões de terra foram trazidos e 285 sulcos foram cavados à mão e limpos de pedras e lixo. As sementes foram semeadas à mão e os sulcos cobertos de terra. 0 campo foi mantido por quatro meses, limpo de feno de trigo, capinado, fertilizado e pulverizado contra fungos de míldio, e um sistema de irrigação foi instalado. A colheita foi realizada em 16 de agosto e rendeu mais de 1000 libras de trigo dourado saudável.

O plantio e a colheita de um campo de trigo em terras no valor de US $\$ 4,5$ bilhões criaram um poderoso paradoxo. 0 campo de trigo era um símbolo, um conceito universal; representava comida, energia, comércio, comércio mundial e economia. Referia-se a má gestão, desperdício, fome no mundo e preocupações ecológicas. Chamou a atenção para nossas prioridades mal colocadas. 0 grão colhido viajou para vinte e oito cidades ao redor do mundo em uma exposição chamada "O Salão Internacional de Arte para o Fim da Fome Mundial", organizado pelo Museu de Arte de Minnesota (1987-90). As sementes foram levadas por pessoas que as plantaram em muitas partes do globo.

0 questionário era composto por questões existenciais sobre os valores humanos, a qualidade de vida e o futuro da humanidade. As respostas foram 
principalmente de estudantes universitários em vários países onde eu falava ou tinha exposições do meu trabalho. Dentro do contexto da cápsula do tempo, o questionário funcionava como um sistema aberto de comunicação, permitindo que nossos descendentes nos avaliassem não tanto pelos objetos que criamos - como é habitual nas cápsulas do tempo -, mas pelas perguntas que fazemos e como respondemos a elas.

O microfilme foi dissecado e colocado em uma cápsula de aço dentro de uma pesada caixa de chumbo em nove pés de concreto. Uma placa marca o local: na borda da floresta indígena, cercada por arbustos de amora. A cápsula do tempo deve ser aberta em 2979, no século XXX, a mil anos da época do enterro.

Existem, ainda dentro do quadro deste projeto, várias cápsulas do tempo planejadas na Terra e no espaço, destinadas a vários prazos no futuro.

Postscript: 0 texto acima, que foi escrito em 1982, ganha agora pungência e relevância após 11/09/2001.

(Denes, 1982)

O New York Times, em 2 de agosto de 1982, repercutiu em suas páginas Wheatfield - A Confrontation, destacando a visão surreal do campo de trigo quando avistado pelos usuários dos barcos:

\section{Ondas urbanas de grão}

Dois acres de trigo da Dakota do Norte ficaram âmbar, ondulando na brisa do mar no aterro de Battery Park City, perto das torres de Wall Street, do Downtown Athletic Club e do World Trade Center. Olhar através deste campo de trigo é ver a Estátua da Liberdade, Ellis Island e o tráfego de barcos como numa ilusão surreal. 
"Caramba!", exclamou uma mulher, parando ontem enquanto seu grupo se dirigia para as balsas da excursão. Mas a anomalia passa despercebida por muitos, que dificilmente param para dar uma olhada.

Agnes Denes, uma artista do SoHo, plantou seis alqueires de trigo, em maio, com a ajuda de um trator e alguns voluntários, incluindo o Public Art Fund. A ideia, disse ela, era fazer "uma intromissão do campo na metrópole, o setor imobiliário mais rico do mundo".

Catando "lixo, pneus e sobretudos velhos" do lixão, segunda a artista, eles adicionaram terra e cavaram 285 sulcos para criar um oásis de "existência simples e natural, sem estresse". Removendo ervas daninha e regando enquanto trabalhadores de escritório observavam das janelas ou "faziam visitas na hora do almoço em trajes de três peças", os cultivadores apreciaram "os insetos, de louvaa-deus a pirilampos, do próprio campo", disse Denes.

Mas o trigo urbano está, de fato, sob tamanho "estresse" que terá que ser colhido um mês antes, de acordo com John Ameroso, o agente de extensão do condado de Kings que é o consultor agrícola de Denes.

"Ele pegou fungo cedo demais, e eu odeio vê-lo partir", disse ela, preparando-se para uma celebração pré-colheita em 11 de agosto. "Estou aqui sete dias por semana - é o meu loft agora."

(Haberman \& Johnston, 1982)

\section{A apanhadora no campo de trigo urbano}

O vento na Upper New York Bay balança um campo dourado de trigo. 0 local é um dos mais valorizados pelo mercado imobiliário internacional e a cor dourada traz uma simbologia da ostentação de ser e estar em Nova York, e não só em Nova York, mas nos territórios financeiros de Nova York. 
O terreno limpo de pedras, sobretudos e restos de cidade serve para arar e semear outras maneiras de ver o cotidiano, novas formas do fazer não-cotidiano, que nos relembra Martins quando este afirmava o "modo capitalista de pensar":

Enquanto modo de produção de ideias, marca tanto o senso comum quanto o conhecimento científico. Define a produção das diferentes modalidades de ideias necessárias à produção de mercadorias nas condições de exploração capitalista, da coisificação das relações sociais e da desumanização do homem. Não se refere estritamente ao modo como pensa o capitalista, mas ao modo de pensar necessário à reprodução capitalista (1978, p. 11).

Assim, é no cotidiano que as atenções são centradas na produção capitalista dos bens de consumo e, portanto, em um pensar-agir-reproduzir baseado no modo capitalista de existência. Vê-se por que o editorialista do New York Times prontamente chama a atenção de seus leitores para a "ilusão surreal" do campo de trigo new yorker, que faz a transeunte exclamar: "Caramba!"

A representação fotográfica mais consumida e famosa de Agnes Denes foi registrada por John McGrail, mas a artista não a aprovou: "Eu fiz a maior parte da fotografia, a propósito, para Wheatfield (...) Eu estou em uma delas; foi um fotógrafo da Life que veio. Ele disse: 'Segure o bastão em sua mão'. Eu disse: 'Isso é ridículo'. Ele disse: 'Apenas segure-o (...) Sim, essa é a única [foto que aparece em todos os veículos]."'4. (Pollack, 2015, p. 44). Esse registro é constantemente reproduzido como um ícone para ser consumado/consumido em sites e revistas pelo mundo.

A proposta de Agnes Denes era refletir a respeito de uma "existência simples e natural, sem estresse" na/da cidade; uma leveza que dialogasse dialeticamente com a leveza indicada por Lipovestsky (2016), a qual, pelo contrário, traz mal-estar e ansiedade por sua imediatez. Dessa forma, as

\footnotetext{
${ }^{4}$ No original: "DENES: I did most of the photography myself, by the way, for Wheatfield. POLLACK: Well, you're in one of them.

DENES: I'm in one of them; that was a Life photographer who came. He said, 'Hold the staff in your hand.' I said, 'That's ridiculous.' He said, 'Just hold it.'

POLLACK: And that's the one that gets printed everywhere.

DENES: Yeah, that's the only one."
}

Dossiê Espaço Urbano e Imaginação Cultural - https://revistaecopos.eco.ufrj.br/

ISSN 2175-8689 - v. 22, n. 3, 2019

DOI: 10.29146/eco-pos.v22i3.27417 
possibilidades são reabertas por Denes, uma vez que "a transformação do cotidiano vem pelo indivíduo que pode alargar fissuras, passar pelos vãos, encontrar intervalos" (Soares, 2001, p. 132).

As fissuras abertas diariamente ao consumir e ser consumido pela cidade, seja pela mistura química de oxigênio, nitrogênio, gás carbônico, gases nobres inalados em trajetos demarcados por indicações numéricas das ruas e edificações; seja pelos caminhos percorridos graças aos mapas mentais configurados pela existência nos territórios permitidos pelas experiências vividas e imaginadas. "0 domínio da realidade chega através do vigor estruturante entre o conhecer e o agir (teoria e práxis) canalizado pelo discurso geográfico" (Soares, 2001, p. 146). Discursos de textos em vários formatos: sintético-ideográficos, analíticodiscursivos, físico-mentais.

Assim como o adolescente Holden Caulfield, ${ }^{5}$ que se vê como um guardião, um salvador, um apanhador de crianças que correm livremente no grande campo de centeio, despreocupadas que o campo esteja localizado na beira de um abismo, o campo de trigo de Agnes Denes nos convida a lançar-nos pelos 8093,71 $\mathrm{m}^{2}$, livres para consumi-lo sensorialmente. Ele é a novidade não-efêmera a cada instante, um combate à leveza pesada do consumismo mediante as sensações e tecnologias do nosso interior, mudando nossa vida (Lipovetsky, 2016, p. 12).

De-compor, sem derrubar o território do mercado financeiro, é um exercício diário para muitos dos moradores de Nova York que passaram pelo campo de trigo...

Proporção - Nem floresta, nem campo de trigo.

\footnotetext{
${ }^{5}$ Holden Caulfield é o protagonista e narrador da obra de 1951 The Catcher in the Rye (no Brasil, "0 apanhador no campo de centeio"), de autoria do norte-americano J. D. Salinger.
} 


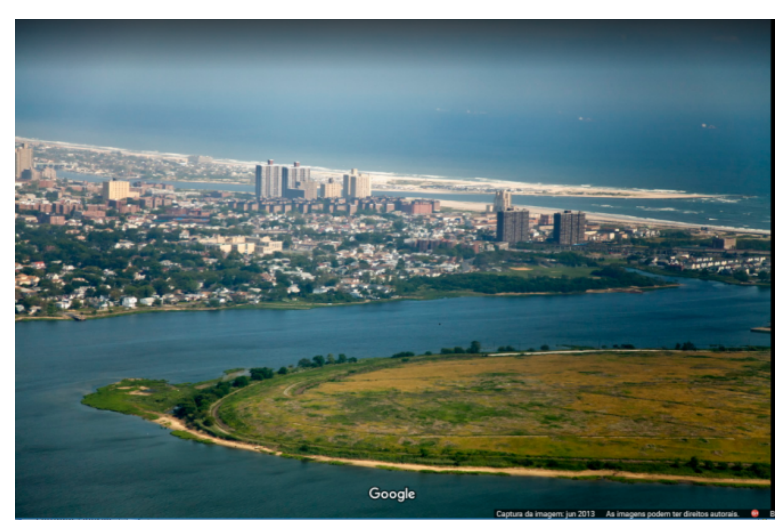

Figura 18 - Jamaica Bay - Nova York. Google Maps

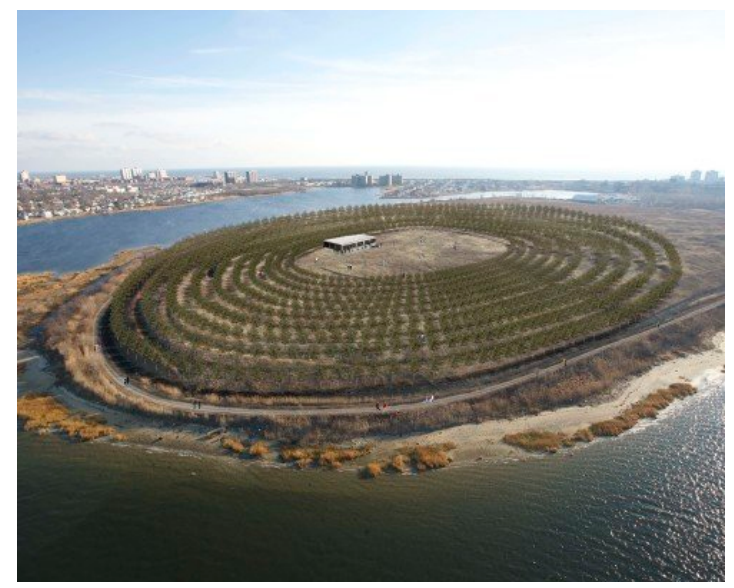

Figura 19 - Ilustração de uma fase do projeto $A$ forest for New York-a peace park for mind and soul - $\quad$ A Project for the Edgemere Landfill, Queens, New York 2014

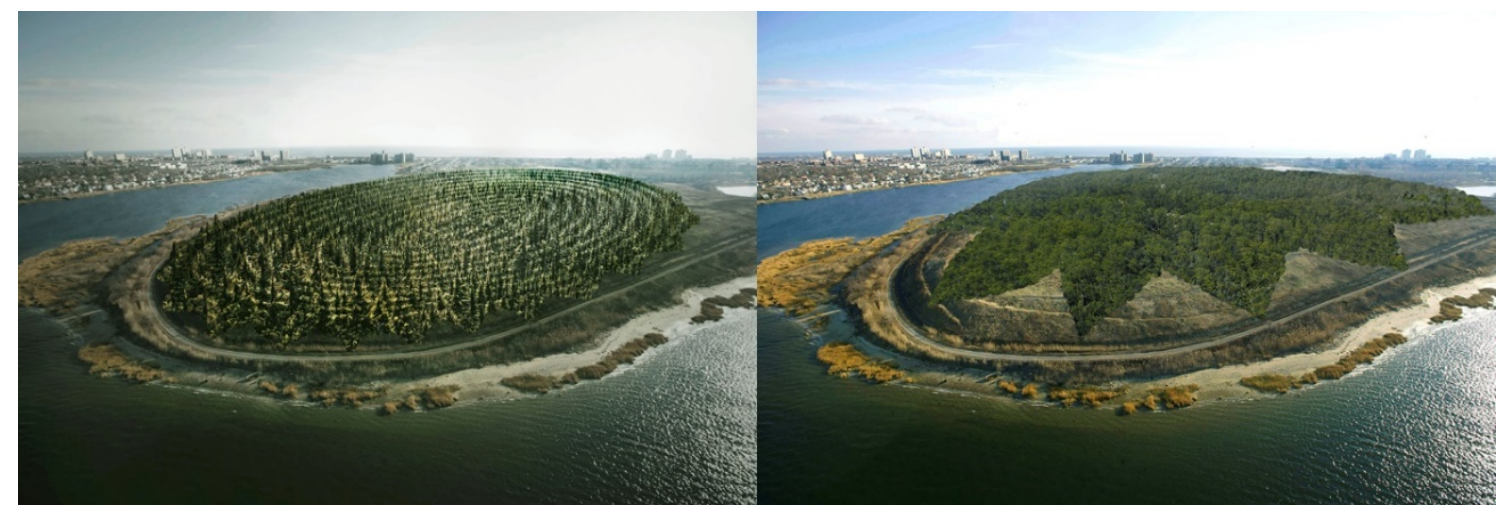

Figura 20 - A forest for New York-a peace park for mind and soul. Queens, Nova York, 2014.

Dossiê Espaço Urbano e Imaginação Cultural - https://revistaecopos.eco.ufrj.br/

ISSN 2175-8689 - v. 22, n. 3, 2019

DOI: $10.29146 /$ eco-pos.v22i3.27417 
Desde 2013, Agnes Denes tem um projeto com um título que pode ser traduzido como "Uma floresta para New York - um parque de paz para a mente e a alma", no qual propõe o plantio de 100.000 árvores com total adaptação ao ambiente do aterro, assim que tiver preparado o solo para receber as sementes.

Até 2019, o projeto não foi posto em ação, apesar de sua aplicabilidade e sua preocupação não apenas estética, mas com a saúde, "através dos efeitos positivos de uma floresta para remover o dióxido de carbono do ar, purificando-o, limpando a água subterrânea e criando um ecossistema saudável através de processos biológicos naturais para toda a cidade e seus arredores" (Denes, 2014).

Caso seja efetivado, ele será um local de visitação aberto, contando ainda com centro de visitantes, café, salas de descanso, um local para celebrações importantes, exposições, concertos, estacionamento ao longo de seus perímetros. Mais importante: pertencerá às pessoas do mundo. Um produto leve para a paz na mente e alma.

\section{A Natureza em seu espaço urbano}

O que é a natureza? o inferno da cidade ou da cultura. O lugar onde o rei foi banido: exatamente o lugar (lieu) do desterro (ban), Ao pé da letra, o subúrbio.

Michel Serres, O Contrato Natural.

A metrópole é um patamar avançado da urbanização, o locus da produção civilizatória, o lugar em que se pode viver com sofisticação. Conforme Santos (2007), não é o tamanho que a define, mas o fato de oferecer a "sofisticação" como ampla possibilidade para seus moradores. É a limitação dessa sofisticação para a grande maioria da população o que diferencia metrópoles como Nova York, Londres e Paris de outras como São Paulo ou Cidade do México (Santos, 2007). 
O campo de trigo da metrópole quer trazer também a leveza do mundo como um valor oferecido pela artista aos moradores da cidade em seu cotidiano. Pode-se considerar que essa oferta é uma forma de pensar o cotidiano desde uma experiência e uma proposta territorial, pelo fato de apresentar um trabalho da artista, e o trabalho é "uma das sedes do cotidiano" (Santos, 2007, p. 94).

Há uma contradição entre o valor do metro quadrado das áreas da cidade, o ícone globalizado do World Trade Center ou das ilhas, e a leveza conceitual da plantação urbana de trigo, em diálogo com a apropriação do solo pelo capital financeiro, especialmente no caso de Battery Park.

No centro da discussão entre o artístico e financeiro globalizado, pensar a emoção como comunicação coloca o artista mais perto do homem comum do cotidiano, pois "o grande artista é livre e sabe que, se não há emoção, ele não se aproxima da verdade [...] 0 existir como condição para ver o mundo. E isso inclui, em primeiro lugar, a emoção. Porque a razão reduz a força de descobrir, porque só a emoção nos leva a ser originais" (Santos, 2002, p. 62-4).

A emoção aliada à leveza, e aliada também à razão, pode ser pensada como "emoração leve", para aproveitar ainda a sugestão de Santos, para quem a "noção de emoração encontra seu fundamento nessas trocas simbólicas que unem emoção e razão" (Santos, 1996, p. 256).

Assim, em nosso cotidiano tecnologizado, a leveza dos aparatos portáteis ou, ao menos, parte deles -, se encontra com a leveza de um campo de trigo, no lugar onde anteriormente estavam pesados escombros de concreto, entre outros materiais descartados pelos citadinos: é o encontro da tecnosfera com a psicosfera.

Para Santos (1996, 2007), essas duas instâncias de análise estão interligadas. A tecnosfera vista como a artificialização do meio ambiente pela ação do trabalho sobre o trabalho e o "espaço geográfico [...] [que] serve de base a uma vida econômica e social crescentemente intelectualizada, graças à complexidade da produção e ao papel que nela exercem os serviços e a informação" (Santos, 1996, p. 204). Mas, ao mesmo tempo em que essa instância se vê dependente da ciência e 
da técnica, cria-se a psicosfera, que resulta das crenças, desejos e hábitos que inspiram e compõem uma filosofia e suas práticas. "A psicosfera é esse conjunto de crenças e ideias, essa esfera da mente, muito mais fácil de ser artificializada talvez que o território porque, através do consumo e da mídia, eu a altero com muita rapidez e grande brutalidade" (Santos, 2007, p. 94). E essa carga de informação no território - redes sem fio, Internet das Coisas, rádio, TV - participam do cotidiano renovado, baseado nos papéis da ciência, tecnologia e informação.

Em sintonia com as propostas indicadas, Lipovetsky vai afirmar que "nos governa uma cultura cotidiana da leveza 'dos meios', pois o universo do consumo não cessa de exaltar sistemas de referência hedonistas e lúdicos" (2016, p. 10).

Contudo, faz-se necessário indicar que Santos analisa a sociedade desde a perspectiva moderna. Conceitos como pós-moderno, hipermodernidade, modernidade líquida, entre outras definições do momento vivenciado nos séculos XX e XXI, não se mostravam relevantes para ele. Isso porque sua proposta de trabalho se colocava em favor da empirização, da busca de coerência na caracterização do momento, considerando que a totalidade se tornou empírica, permitindo a teorização (Santos, 2007, p. 83).

Parece apropriado pensar a "emoração leve" para compreender as relações e os arranjos espaciais, expressos nas unidades paisagísticas da cidade de Nova York com a ocupação vegetal de Battery Park. Pela metodologia exposta por Agnes Denes, pode-se perceber sua preocupação tecno-científica. Ao mesmo tempo, ela indica e sugere um desfrutar da cidade, e que Battery Park não quer ser um campo, não almeja se tornar uma Nova York rural. Almeja a comunicação na cidade, pois ela, a cidade, é "o lugar ideal, porque é o lugar onde todo o mundo se comunica" (Santos, 2007, p. 113). E isso se divisa em sua obra. 
Ilação

Este artigo buscou tratar da relação entre a cidade e a arte no espaço, ressaltando a leveza de um campo de trigo na paisagem urbana, propondo uma temporalidade diferente na reconstrução dos usos mais comuns da construção civil, dispostos em grandes edifícios e suas vias de acesso e praças, na icônica Nova York, cidade global por excelência.

Amparado bibliograficamente em fontes interdisciplinares, o artigo colocou possibilidades de análise visando não apenas a descrição da obra de Agnes Denes, mas uma tentativa de pensá-la dentro de um contexto mais denso, envolvendo a cidade e o espaço.

A leveza conceitual do campo de trigo no espaço urbano contradiz diretamente as propostas capitalistas do uso do solo urbano pelo mercado financeiro global. Colher trigo em Nova York, observando o World Trade Center, é um modo de questionar a hegemonia do capital financeiro na cidade. A efemeridade do tempo e do espaço dessa ocupação suspende por alguns momentos o cotidiano dos citadinos e dos turistas. 0 tempo de incorporação dessa paisagem no cotidiano, meses depois, é suspenso também durante a colheita, motivada pelo aparecimento de mofo no trigal. Ao fim, dando continuidade ao diálogo entre a obra e os movimentos do capital financeiro, a ocupação terminou com a construção de áreas residenciais, parques, cais e centros culturais em seu lugar, assumindo o papel corriqueiro da urbanização com base no valor imobiliário. Nada diferente do que o que a própria artista imaginava que aconteceria.

Já a floresta pensada e repensada em seus projetos ainda não conseguiu ser efetivada. Entretanto, em abril de 2019, na impossibilidade de participar de uma conferência para a qual fora convidada pela Harvard University Graduate School of Design, Denes enviou um manifesto escrito e uma obra plástica com indicações para sua vida-obra. Entre as afirmações feitas por ela, destaca-se: 


\begin{abstract}
Quando comecei minha jornada, quis mudar o mundo, reavaliar todo o conhecimento e colocá-lo em forma visual para melhor compreensão. Quando trabalhei, percebi que minha tarefa era um pouco mais complexa do que o que poderia ser alcançado por uma única mente sem ajuda ou fundos. Isso não me abalou nem um pouco, e eu continuei estabelecendo e atingindo metas. Querer mudar o mundo se transformou em uma produção artística única de uma vida inteira de criação e visualização de processos invisíveis, como matemática, lógica, processos de raciocínio e assim por diante.

Este processo de reavaliação e visualização tornou-se um processo de oferecer à humanidade soluções benignas para alguns de seus problemas, e envolveu uma infinidade de disciplinas.

Então, agora, pergunte a si mesmo: onde você está na sua idade de querer mudar as coisas? Que montanha resta subir, mover ou eliminar? Não pretendo contar-lhes verdades ou objetivos últimos, apenas que vocês devem procurá-los. É essa busca que é a jornada, e é tão preciosa quanto o destino. Questionar tudo. Não apenas porque você deveria, mas porque você pode aprimorar sua capacidade de fazê-lo. A melhor criatividade vem do questionamento do status quo. Sua mente será sua salvação em um mundo conturbado, e nunca haverá um tempo em que nosso mundo não esteja conturbado. (DENES, 2019).
\end{abstract}

De outubro de 2019 a janeiro de 2020 acontece a primeira retrospectiva da obra de Agnes Denes em Nova York, intitulada Agnes Denes: Absolutes and Intermediates.

A leveza de uma obra de arte no espaço urbano contrasta com seu uso corrente no capitalismo, principalmente em uma cidade global como Nova York. Ao possibilitar a suspensão do cotidiano para os citadinos, Denes adiciona aos espaços da cidade novas dimensões potenciais e agenciamentos até então não imaginados. Questionar tudo: eis o que nos resta.

\title{
Referências bibliográficas
}

CAUQUELIN, Anne. Arte Contemporânea: Uma introdução. São Paulo: Martins Fontes, 2005.

DENES, Agnes. "Rice/Tree/Burial with Time Capsule (1968)”. Disponível em: <http://www.agnesdenesstudio.com/works2.html>. Acesso em: 17 jul. 2019.

\section{Dossiê Espaço Urbano e Imaginação Cultural - https://revistaecopos.eco.ufrj.br/}

ISSN 2175-8689 - v. 22, n. 3, 2019

DOI: 10.29146/eco-pos.v22i3.27417 
"Two acres of wheat planted and harvested by the artist on the Battery Park landfill, Manhattan, Summer 1982". Disponível em: <http://www.agnesdenesstudio.com/works7.html>. Acesso em: 17 jul. 2019.

"A forest for New York - A peace park for mind and soul. A Poject for the Edgemere Landfill, Queens, New York, 2014". Disponível em <http://www.agnesdenesstudio.com/works1.html>. Acesso em: 17 jul. 2019.

"Pioneering conceptual artist Agnes Denes addresses the students of the Harvard Graduate School of Design". Disponível em: <https://bit.ly/2YqNrE4 . Acesso em: 20 jul. 2019.

GENDLIN, Eugene T. "Experiencing: A variable in the process of therapeutic change”. American Journal of Psychotherapy, vol. 15, p. 233-245. 1961. Disponível em: <https://focusing.org/gendlin/docs/gol-2082>. Acesso em: 17 jul. 2019.

HABERMAN, Clyde. \& JOHNSTON, Laurie. "Urban Waves of Grain”. New York Times, 1982, Aug. 2. Disponível em: <https://nyti.ms/29KeEXQ>. Acesso em: 17 jul. 2019.

HELLER, Agnes. O cotidiano e a história. São Paulo: Paz e Terra, 2000.

LIPOVETSKY, G. Da leveza: Rumo a uma civilização sem pes. Trad. Idalina Lopes. Barueri: Manole, 2016.

MARTINS, José de Souza. Sobre o modo capitalista de pensar. São Paulo: Hucitec, 1982.

POLLACK, Maika. “Agnes Denes”. Interview Magazine. p. 44-45; 146-148. 2015. Disponível em <https://www.interviewmagazine.com/art/agnes-denes>. Acesso em: 17 jul.2019.

SANTOS, Milton. A natureza do Espaço: Técnica e tempo, razão e emoção. São Paulo: Hucitec, 1996.

. O país distorcido. São Paulo: PubliFolha, 2002.

Encontros. Org. Maria Angela P. Leite. Rio de Janeiro: Beco do Azougue, 2007.

SERRES, Michel. O contrato natural. Rio de Janeiro: Nova Fronteira, 1991.

SMITH, Patti. "on new york city" (1969). (1min15s). Youtube. 2011. Disponível em: <https://youtu.be/ZpSYIzxtoTs>. Acesso em: 17 jul. 2019.

SOARES, Maria Lúcia de Amorim. Girassóis ou Heliantos: Maneiras criadoras para o conhecer geográfico. Sorocaba: Teaser/LINC, 2001. 
WEISS, Jeffrey. "Land Art". ArtForum Magazine, 47, \#1. 2008. Disponível em: <https://www.artforum.com/print/200807/land-art-20912>. Acesso em: 17 jul. 2019.

ZANELLA, Andréa Vieira; BALBINOT, Gabriela; PEREIRA, Renata Susan. "Recriar a (na) renda de bilro: analisando a nova trama tecida". Psicologia: Reflexão e Crítica, 3(13), p. 539-547. 2000. Disponível em: <http://dx.doi.org/10.1590/S0102$79722000000300021>$. Acesso em: 17 jul. 2019. 